https://journal.uwgm.ac.id/index.php/abdimasmahakam

E-ISSN: 2549-5755

Januari 2020, Vol. 4 No. 01

Received: Agustus 2019

Accepted: November2019

Published: Januari 2020

Article DOI: http://dx.doi.org/ 10.24903/jam.v4i1.776

\title{
Edukasi Kesehatan Reproduksi Remaja
}

\author{
Natiqotul Fatkhiyah, \\ Sekolah Tinggi Ilmu Kesehatan Bhakti Mandala Husada Slawi \\ natirozak@gmail.com \\ Masturoh, \\ Sekolah Tinggi Ilmu Kesehatan Bhakti Mandala Husada Slawi \\ masturoh87@gmail.com \\ Dwi Atmoko \\ Sekolah Tinggi Ilmu Kesehatan Bhakti Mandala Husada Slawi \\ dwiatmoko@gmail.com
}

\begin{abstract}
Abstrak
Periode remaja sebagai masa peralihan usia anak hingga dewasa. Masa ini sangat penting karena merupakan penentu masa depan bangsa Kesehatan reproduksi remaja merupakan kondisi sehat yang meliputi sistem, fungsi, dan proses reproduksi. Edukasi kesehatan reproduksi bagi remaja merupakan hal penting sebagai upaya menghindari kekerasan dan penyimpangan seksual berbasis gender bagi remaja. Kurangnya edukasi terhadap hal yang berkaitan dengan reproduksi mampu memicu terjadinya hal-hal yang tak diinginkan diantaranya seks bebas, kekerasan seksual dan perilaku menyimpang. Institusi sebagai wahana yang tepat untuk menyampaikan pemahaman kesehatan reproduksi remaja dengan tepat, selain peran orang tua dan keluarga. Tujuan pengabdian kepada masyarakat ini adalah memberikan edukasi kesehatan reproduksi remaja yang meliputi tumbuh kembang remaja dan permasalahan kesehatan reproduksi remaja. Sasaran kegiatan adalah siswa klas XII SMK Semesta Bumiayu Kabupaten Brebes Provinsi Jawa Tengah sejumlah 120 remaja. Hasil kegiatan remaja proaktif dalam diskusi terkait permasalahan kesehatan reproduksi dan mengetahui periode pubertas serta tahapan tumbuh kembang remaja. Perlunya edukasi kesehatan reproduksi dengan metode kognitif dan proaktif lebih menekankan bagaimana dalam kegiatan pembelajaran remaja diajak untuk berpartisipasi atau terlibat aktif (ranah proaktif) mengutarakan pendapatnya tentang suatu topik (ranah kognitif). Metode kognitifproaktif dapat dilakukan antar teman sebaya, peer group, ataupun dengan seorang fasilitator.
\end{abstract}

Kata Kunci: remaja; edukasi; kesehatan reproduksi.

\section{Pendahuluan}

Word Health Organization mendefinisikan remaja sebagai manusia yang berusia dari 10 sampai 19 tahun. Remaja merupakan penduduk dengan usia 10 - 18 tahun (Peraturan Menteri Kesehatan RI Nomor 25 tahun 2014) dan Badan Kependudukan dan Keluarga Berencana 


\section{(A) ABDIMAS}

https://journal.uwgm.ac.id/index.php/abdimasmahakam

E-ISSN: 2549-5755

Januari 2020, Vol. 4 No. 01

(BKKBN) mengkategorikan remaja sebagai penduduk dengan umur 10 - 24 tahun dan belum pernah menikah. Periode remaja adalah masa transisi dari usia anak hingga dewasa. Ini merupakan saat yang sangat penting karena merupakan penentu masa depan bangsa.Di tahun 2010, jumlah remaja yang berusia $10-24$ tahun berkisar 64 juta atau 27,6\% dari keseluruhan penduduk Indonesia dengan jumlah 237,6 juta jiwa menurut Sensus Penduduk tahun 2010. Hal ini yang menjadikan masa remaja adalah saat yang amat krusial karena remaja merupakan tonggak penerus bangsa. Oleh karena itu, sangat perlu untuk dipersiapkan sebagai manusia sehat jasmaniah, mental dan spiritual. Namun faktanya, beragam penelitian memaparkan bahwa sebagian besar remaja memiliki kompleksitas permasalahan. Persoalan tersebut meliputi TRIAD Kesehatan Reproduksi Remaja yaitu Seksualitas, HIV, AIDS dan Napza. Selain itu, masih minimnya pengetahuan remaja mengenai Kesehatan Reproduksi dan usia pernikahan pada perempuan yang rendah dengan rerata 19,8 tahun merupakan permasalahan tersendiri (SDKI 2007).

Menurut data BKKBN tahun 2010 menyatakan bahwa 34,5\% remaja laki-laki dan 33,3\% remaja perempuan mulai berpacaran pada usia 15 tahun. Hal ini merupakan suatu persoalan penting karena pada usia remaja dikhawatirkan belum memiliki keterampilan hidup (lifeskill) yang belum memadai sehingga dianggap berisiko melakukan hubungan seks pra nikah dan pacaran yang tidak sehat. Setiap orang berhak mendapatkan pelayanan kesehatan reproduksi yang berkualitas, aman serta mampu dipertanggungjawabkan, menjamin kesehatan wanita dalam rentang reproduksi agar dapat melahirkan generasi yang sehat, bermutu, sehingga terjadi penurunan Angka Kematian Ibu (Peraturan Pemerintah Nomor 61 Tahun 2014).

Proses reproduksi juga berkaitan dengan pembuatan keputusan dalam kehidupan wanita. Hal ini dapat didukung dari pengadaan informasi dan pelayanan yang mampu memenuhi kebutuhan kesehatan reproduksi yang optimal. Persoalan yang sering terjadi dalam lingkup reproduksi tidak dapat terpisahkan dari hubungan antara laki-laki dan perempuan. Sepanjang siklus hidup manusia terjadi masalah kesehatan reproduksi seperti rendahnya informasi tentang kesehatan reproduksi, pergaulan bebas pada remaja, kehamilan pada remaja, dan aborsi yang tidak aman.

Penyebab utama masalah kesehatan reproduksi yang dihadapi perempuan terkait dengan status perempuan di masyarakat, karena menyebabkan perempuan kehilangan kendali terhadap kesehatan dan fertilitasnya. Kelompok perempuan lebih rentan mengadapi risiko kesehatan reproduksi, seperti pemakaian alat kontrasepsi. kehamilan, melahirkan, dan aborsi yang tidak aman. Struktur alat reproduksi perempuan lebih rentan secara sosial maupun fisik terhadap Infeksi Menular Seksual (IMS), termasuk HIV/AIDS. Kelompok laki-laki juga rentan terhadap masalah kesehatan reproduksi, terutama IMS termasuk HIV/AIDS. Permasalahan perilaku pada usia remaja, salah satu penyebabnya adalah adanya perubahan organ biologik sebagai akibat organ-organ reproduksi yang telah matang.

Data Riskesdas 2010 menyampaikan persentase remaja yang pernah mendapatkan penyuluhan Kesprp di Indonesia sebanyak 25.1\%. target Pemerintah meningkatkan penyuluhan komprehesif program Kespro remaja usia dibawah 15 tahun sebesar 65\%, namun hanya tercapai 11,4\% di tahun 2011 (Mulyadi, 2012). Minimnya Pengetahuan Kespro remaja berdampak pada aktivitas seksual diantaranya $15.9 \%$ remaja laki-laki dan $10.1 \%$ remaja putrid di usia 18 tahun sudah pernah melakukan hubungan seksual, 771 dari 10.000 remaja usia 18-19 tahun pernah mengalami kehamilan (Riskesdas 2010) 
Survei Kespro Remaja di Indonesia tahun 2007 menyatakan bahwa pengetahuan remaja mengenai kesehatan reproduksi masih relatif rendah. Sebesar $13 \%$ remaja perempuan menyatakan tidak mengetahui perubahan fisik yang terjadi pada tubuhnya dan 47,9\% sama sekali tidak mengetahui masa subur dalam siklus menstruasi (Kemenkes, 2010). Di samping itu, sebagian besar remaja tidak mengetahui cara untuk menghindari infeksi HIV. Hanya terdapat $14 \%$ remaja perempuan yang menyatakan bahwa pantang untuk melakukan hubungan seksual sebelum menikah, $25 \%$ remaja laki-laki menyebutkan bahwa penggunaan kondom sebagai perlindungan sebelum berhubungan seksual dan $8 \%$ yang menyatakan akan membatasi frekuensi hubungan seksual dan tidak berganti-ganti pasangan untuk menghindari penularan infeksi HIV dan AIDS (BKKBN, 2012). Selain itu, hampir sebagian besar $(47,8 \%)$ penderita AIDS di Indonesia berusia 20 hingga 29 tahun.

Beragam jenis Penyakit Menular Seksual semakin banyak terjadi pada usia remaja. Bahkan perilaku seksual berisiko pun semakin sering dilakukan oleh para remaja dan sangat disayangkan tidak sedikit usia remaja yang melakukan pengguguran kandungan (aborsi) yaitu mencapai angka 28,4\% dari kasus aborsi yang ada (BKKBN, 2008). Sensus Penduduk pada tahun 2010 menunjukkan bahwa remaja yang berusia 10-19 tahun berjumlah 43.5 juta atau $18 \%$ dari total penduduk. Masalah kesehatan reproduksi dan seksual remaja menjadi hal penting bagi pembangunan nasional berkaitan besarnya populasi penduduk remaja dan dampak jangka panjang yang dapat ditimbulkan dari permasalahan kesehatan reproduksi dan seksual remaja. Sementara, usia remaja masih rentan terhadap masalah kesehatan reproduksi dan seksual, seperti perkawinan remaja, pengetahuan kesehatan reproduksi dan seksual yang rendah, kehamilan di usia muda, kehamilan tidak diinginkan, penyakit menular seksual seperti HIV dan AIDS, aborsi yang tidak aman, maupun kekerasan berbasis gender. Hasil Riskesdas pada tahun 2010, sebanyak 41,9\% usia perkawinan pertama berada pada kelompok usia 15-19 tahun serta 33,6\% terjadi pada kelompok usia 20-24 tahun (Kemenkes, 2010).

Menurut Country Representative Rutgers WPF Indonesia, sebuah organisasi pusat keahlian dalam kesehatan reproduksi dan pencegahan kekerasan berbasis gender, masih banyak guru atau pengajar yang kurang paham cara menyampaikannya dengan baik. Beberapa diantaranya, masih sungkan membicarakan kesehatan reproduksi karena masih dianggap tabu di masyarakat. Hal ini tentunya menjadi tantangan tersendiri dalam upaya mengurangi kekerasan seksual pada remaja.

\section{Metode}

Kegiatan pengabdian masyarakat dengan tema Kespro remaja menggunakan metode Edukasi dengan sasaran 150 siswa kelas XII SMK Semesta Bumiaya Kab. Brebes Provins Jawa Tengah. Tahapan pelaksanaan kegiatan seperti; melakukan survey lokasi, pengurusan perijinan untuk melakukan kegiatan penyuluhan, menyusun jadwal kegiatan yang disesuaikan dengan jadwal pembelajaran siswa. Selanjutnya pelaksanaan penyuluhan dengan materi Tumbuh Kembang Remaja dan Permasalahan yang terkait Kespro Remaja dilanjutkan dengan tanya jawab dan diskusi terkait tema Kespro Remaja. Kegiatan ini diakhiri dengan pengisian form kuisioner terkait permasalahan kesehatan reproduksi remaja.

\section{Hasil dan Pembahasan}

Tabel 1. Rerata Usia Responden

\begin{tabular}{llll}
\hline Variabel & Mean & Standar Deviasi & Min-Max \\
\hline
\end{tabular}


https://journal.uwgm.ac.id/index.php/abdimasmahakam

E-ISSN: 2549-5755

Januari 2020, Vol. 4 No. 01

\begin{tabular}{llcc}
\hline Usia & 16.6 & 0.76 & $15.05-16.82$ \\
\hline
\end{tabular}

Tabel 2. Jenis Kelamin Responden

\begin{tabular}{lll}
\hline Variabel & Jumlah & Persentase \\
\hline Laki-laki & 34 & $28.3 \%$ \\
\hline Perempuan & 86 & $71.7 \%$ \\
\hline Jumlah & 120 & $100.0 \%$ \\
\hline
\end{tabular}

Djamhoer (2005) menyatakan edukasi sangat penting dalam upaya meningkatkan kesehatan reproduksi remaja. Adanya perilaku seks berisiko terjadi pada usia remaja dan rendahnya pengetahuan Kespro menjadikan pendidikan kesehatan reproduksi dan seksual penting untuk diberikan (Pakasi \& Reni, 2013). Pendidikan kesehatan reproduksi dan seksualitas pada pemuda merupakan hal yang penting. Hal tersebut merupakan bagian yang diperlukan dalam pencapaian tu gas tumbuh kembang pada remaja. Donovan (1998) memaparkan bahwa tujuan dari pendidikan seksual adalah untuk memberikan informasi pada remaja agar mereka mampu memberdayakan diri untuk membangun nilai positif dan memiliki keterampilan yang mendukung mereka untuk membuat keputusan yang bertanggung jawab demi menjadi orang dewasa yang sehat secara seksual. Sementara itu, menurut Fine dan McClelland dalam Paksi \& Reni tahun 2013 menyatakan bahwa dalam memberikan edukasi seksualitas, diperlukan diskusi kebutuhan seksual mereka. Hal ini bertujuan agar mereka mampu membangun subjektivitas dan mampu membangun rasa tanggung jawab sebagai makhluk seksual. Dengan begitu, maka penting untuk menganggap remaja sebagai makhluk yang aktif secara seksual.

IPPF(2010) dalam Pakasi\&Reni, 2013 penting untuk memberikan konsep pendidikan seksualitas komprehensif bagi remaja yang memiliki dasar bahwa remaja berhak untuk memiliki pengetahuan, keterampilan, sikap dan nilai. Ini bertujuan agar mereka mampu menentukan dan menikmati seksualitas fisik maupun psikis secara individual dan satu sama lain. Sekedar pemberian informasi pun dirasa masih belum cukup. Remaja harus memiliki kesempatan untuk mengembangkan keterampilan dalam membangun sikap dan nilai positif terhadap seksualitas yang mereka miliki. Maka, pendidikan seksual yang benar bagi remaja sangat penting. Pentingnya Pendidikan seksual bagi usia remaja bertujuan membimbing serta penjelasan terkait perubahan fungsi organ seksual merupakan tahapan yang harus dialami dalam kehidupan serta pemahaman nilai seksualitas (Yuniarti, 2007)

\section{Simpulan dan rekomendasi}

Pendidikan reproduksi pada remaja merupakan hal yang penting untuk diberikan. Apalagi dengan semakin meningkatnya penyimpangan dan masalah seksual dan reproduksi pada remaja, seperti seks bebas, abortus, dan penyakit menular seksual (PMS). Pendidikan reproduksi pada remaja perlu disesuaikan dengan perkembangan pada remaja. Pada usia remaja dalam pembelajaran cenderung ingin tahu terhadap suatu hal. Metode pembelajaran yang lebih sesuai adalah dengan metode diskusi untuk menerima suatu kesimpulan dan tidak kaku secara penyampaian materi. Metode pembelajaran tersebut bertujuan supaya pesan edukasi dapat diterima dan sesuai dengan tugas perkembangannya. 


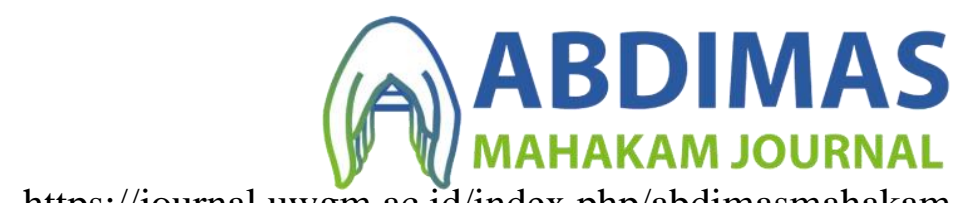

https://journal.uwgm.ac.id/index.php/abdimasmahakam

E-ISSN: 2549-5755

Januari 2020, Vol. 4 No. 01

Pendidikan kesehatan reproduksi dengan metode kognitif dan proaktif lebih menekankan bagaimana dalam kegiatan pembelajaran remaja diajak untuk berpartisipasi atau terlibat aktif (ranah proaktif) mengutarakan pendapatnya tentang suatu topik (ranah kognitif), dilihat dari aspek positif dan negatifnya akibat yang akan ditimbulkan sampai remaja tersebut dapat menyimpulkan sendiri apakah permasalahan tersebut baik atau tidak bagi seorang remaja. Metode ini dirasakan lebih efektif dibandingkan pendidikan kesehatan reproduksi yang hanya melalui metode ceramah di kelas yang hanya berkalan satu arah. Pendidikan kesehatan reproduksi metode kognitif-proaktif dapat dilakukan antar teman sebaya, peer group, ataupun dengan seorang fasilitator. 
https://journal.uwgm.ac.id/index.php/abdimasmahakam

E-ISSN: 2549-5755

Januari 2020, Vol. 4 No. 01

\section{Daftar Pustaka}

Direktorat Remaja dan Perlindungan Hak Reproduksi \& Pusdiklat BKKBN. 2006.

Modul Workshop Konseling Kesehatan Reproduksi Remaja

Dianawati, Ajen. 2006. Pendidikan Seks Untuk Remaja. Jakarta: PT. Kawan Pustaka.

Ditjen Pengendalian Penyakit dan Penyehatan Lingkungan, Kemenkes RI, 2010.

Donovan P. School based sexuality education: the issues and challenges. Family Planning Perspectives 2008; 30, 4: 188-193

Notoadmodjo, S. 2010. Promosi Kesehatan Teori dan Aplikasi. Jakarta: Rineka Cipta.

Pakasi, Diana T \& Reni.K. 2013. Antara Kebutuhan dan Tabu: Pendidikan Seksualitas dan Kesehatan Reproduksi bagi Remaja di SMA. Makara Seri Kesehatan, 2013, 17(2): 79-87.

Potter dan Perry. 2009. Fundamental of Nursing Buku I Edisi 7. Jakarta: Salemba Medika. Survei Kesehatan Reproduksi Remaja, Kemenkes RI, 2007.

Tarigan, A. 2010. Efektivitas Metode Ceramah dan Diskusi Kelompok terhadap Pengetahuan dan Sikap tentang Kesehatan Reproduksi pada Remaja di Yayasan Pendidikan Harapan Me kar Medan. Respiratory Disertasi Universitas Sumatera Utara. Medan.

Yuniarti, Debi. 2007. Pengaruh Pendidikan Seks Terhadap Sikap Mengenai Seks Pranikah Pada Remaja. Jakarta: Fakultas Psikologi, Universitas Gunadarma.

Laman Badan Penelitian dan Pengembangan Kesehatan Kementerian Kesehatan RI Tahun 2010. Riset Kesehatan Dasar (RISKESDAS). (online) diakses pada 27 September 2019

Badan Kependudukan dan Keluarga Berencana Nasional (BKKBN). 2012. Genre Goes to School: Yang Muda Harus Berencana. (online). diakses pada 27 September 2019. 